\title{
Implementation of Strategies in Shaping Effective and Superior Schools (Multisite Study at SMP Islam al-Azhaar Tulungagung and SMP Negeri 1 Tulungagung)
}

\author{
Tri Prasetiyo Utomo ${ }^{1}$, Imam Saerozi ${ }^{2}$ \\ ${ }^{1}$ Institut Agama Islam Tribakti (IAIT) Kediri, ${ }^{2}$ IAINTulungagung \\ Iprasetiya1984@gmail.com, ${ }^{2}$ saeroziimam@gmail.com
}

\begin{abstract}
Implementation of strategies informing effective schools is a follow-up to the process of formulating strategies (planning) by various parties responsible for the process of effective school development. The implementation of the strategy is an action to achieve the educational objectives (effective schools) through the stages that have been set in the form of program structure, budget, operational standards, supervision, and evaluation. This research explore in-depth the implementation of strategies in Junior High School (SMP) Islam al-Azhaar Tulungagung and Junior High School (SMP) Negeri 1 Tulungagung. This research uses qualitative research methods, using phenomenological field studies. Meanwhile, data collection techniques are conducted through in-depth interviews, observations, and passive participants in the field as well as using other literature relevant to the concept of implementing strategies informing effective schools. The results showed that the implementation of strategies in shaping schools was effectively carried out through internal processes and external processes. This process will result in effective learning, effective teaching, and a conducive environment.
\end{abstract}

Key Word: Effective Schools, Implementation of Strategies

\begin{abstract}
Abstrak
Implementasi strategi dalam membentuk sekolah efektif merupakan tindak lanjut dari proses perumusan strategi (perencanaan) oleh berbagai pihak yang bertanggung jawab atas proses pembangunan sekolah efektif. Penerapan strategi merupakan tindakan untuk mencapai tujuan pendidikan (sekolah yang efektif) melalui tahapan yang telah ditetapkan dalam bentuk struktur program, anggaran, standar operasional, pengawasan dan evaluasi. Penelitian ini menggali secara mendalam pelaksanaan strategi di Sekolah Menengah Pertama (SMP) Islam al-Azhaar Tulungagung dan Sekolah Menengah Pertama (SMP) Negeri 1 Tulungagung. Penelitian ini menggunakan metode penelitian kualitatif, dengan pendekatan studi lapangan fenomenologis. Sementara itu, teknik pengumpulan data dilakukan melalui wawancara mendalam, observasi, dan peserta pasif di lapangan serta menggunakan literatur lain yang relevan dengan konsep penerapan strategi dalam membentuk sekolah efektif. Hasil penelitian menunjukkan, bahwa implementasi strategi dalam membentuk sekolah dilakukan secara efektif melalui proses internal dan eksternal. Proses ini akan menghasilkan pembelajaran efektif, pengajaran efektif dan lingkungan yang kondusif.
\end{abstract}

Kata Kunci: Implementasi Strategi, Sekolah Efektif 


\section{Introduction}

Effective school building strategies are one of the alternative solutions to continue to play a role, compete, and survive in educating the nation's children. An effective school is a school that is able to deliver its students to achieve significant achievement progress. ${ }^{1}$ These achievements include academic and nonacademic achievements. Creative schools will certainly do their utmost to answer all challenges, needs, and social psychos that are expected by users of educational services, namely parents or guardians. Cooperation between community elements, stakeholders, and solid institutional managers will certainly produce excellent programs in schools. These programs are alternative measures to answer the challenges, needs, and psycho-social community users of educational services. Thus, ijtihad and the preparation of strategic measures to support the formation of effective schools are needed to continue to play a role, compete, and survive in educating the lives of the nation's children according to the needs of their time.

The position of educational institutions in Indonesia is faced with two dilemmas, namely significant technological

${ }^{1}$ Peter Mortimore, School Effectiveness and the Management of Effective Learning and Teaching (London: The Internaional Congress Four School advances and the conservation of religious values of religiosity that are quite strong. First, the advancement of technology builds paradigms in the technological society and the advancement of civilization is everything and means to survive in the future. Second, conservative religious values of religiosity are quite visceral. This situation is considered by many religious rituals that are quite developed in the community. These include ceremonial activities of grand recitation, sectarian traditions and religious organizations, as well as a lifestyle in dress that reflects religious values. The first state (technological advancement) demands that people live dynamically, adaptively, and creatively to answer the challenges of rapid change. While conservative values of religiosity become a means of strengthening character, morality, and ethics that must be maintained continuously. Therefore, the effort to conduct synthesis between the two became the efforts of educational institutions to present updated educational programs in order to answer the changes and challenges of the times.

Effectiveness and Improvement, Noorkoping, Sweden, 1993). 8. 
Effective educational institutions will strive to present creative learning programs. The program will not run optimally without the support of clear, planned, and in accordance with established operational standards. This related to regard to the implementation of strategies in forming effective schools, it is necessary to display guidelines for implementing strategies in forming effective schools. Implementation of strategies in forming effective schools are the stages of implementing institutional programs that are prepared based on, planning, implementing strategies, and evaluating strategies.

\section{Theoretical Studies}

Murniati, in Ulfah Irani Z, stated that strategic implementation is a process consisting of several stages including environmental observation, strategic formulation, implementation/strategic implementation, then the implementation of evaluation and control of the implementation process. Furthermore, Murniati and Usman describe strategic implementation as a stage of action from strategic management as an effort to realize the program that has been set at the stage of strategic formulation. ${ }^{2}$

2 Ulfah Irani Z., Murniati AR, and Khairuddin, "Implementasi Manajemen Strategik Dalam Upaya
In strategic implementation activities, there are several components that should be of concern to top management. Some of these elements are programs, budgets and operational procedures. The program is simply defined as the steps that must be implemented by all functional elements of the organization according to the established planning. Procedures are measures that have been prepared systematically, regularly, and must be implemented according to the procedure, in other words is the standard operational procedure (S.O.P). Then, the budget is all the costs required for the implementation of the programme and the implementation of the procedures stated in units of money.

Statement that have the same substance are also expressed by Priyono, namely the process of strategic implementation has five important elements including environmental analysis, mission and objective determination, strategic formulation, choice and strategic application, as well as evaluation or control of the process of the dynamics of program implementation. The five elements in the strategic implementation process above have a dependency on each other.

Harapan," Jurnal Administrasi Pendidikan Pascasarjana Universitas Syiah Kuala, 2, 4 (2014): 58-70. 
Thus, the environmental analysis will determine the determination of the mission of the organization or educational institution. It is difficult for organizations or educational institutions to determine the mission or philosophy that must be embraced by the organization, without information and findings at the analytical stage of the environment, both internal and external environments. After the establishment of the mission, the direction and objectives of the organization will become clear and can be socialized to all functional members of the organization. Of course, in this case the objectives of the organization become the priority goals that will be achieved by each organization. It is explained by a clear direction and objectives and understood by all members of the organization all activities and dynamics contained in it, that will be easier to achieve the goal or objectives.

A. David Hunger explains strategic implementation is the action of management realizing its strategy and policies through action steps in the form of programs, budget details, and procedures (SOP). ${ }^{3}$ According to David, the context of strategic implementation emphasizes on three aspects. First, the program is defined as a clearly stated and detailed activity or the steps required by the educational institution to complete the planning with a disposable tempo. The program will result in the restructuring of educational organizations/ institutions, cultural changes in the organization, or can be interpreted as new steps in future research efforts. As an example of an educational institution, in this case the top manager or principal will conduct a thorough observation or ask about the school in the future to all staff, namely vice of curriculum, student, public relations, facilities. Challenges will be faced, what needs are required by users of educational institutions services and cooperation with which parties if able to make a positive contribution to educational institutions.

Implementation also includes a series of advertising/promotion/publication programs with the aim of introducing, encouraging consumer, and customer interest in the products and services of educational institutions or companies. For example, in implementing strategies and policies, educational institutions will socialize through advertising, billboard, and flyer to their environment or pockets there are many consumers who use services 
and products of institutions. Moreover, they will cooperate with other institutions that can be suppliers or networks of cooperation. Then, they offer a special program such as scholarships, educational institution facilities, as well as the quality and excellence of the institution.

Second, the budget is a program expressed in the form of units of money. Each predetermined program will be stated in detail, clearly, and in detail at a cost. These details will assist management in planning and controlling the course of the organization/institution. Related to regard to the budget, educational institutions should ask for a definite and clear presentation of the level of return on investment that has been issued. This process is called the hurdle rate before the headmaster approves a program. That is to ensure that the new program that has been detailed in the cost unit will have a significant impact on the company's profit performance that is valuable to stakeholders (in the world of education) the program that has been proclaimed in units of cost will have a positive impact on students in particular and the entire community of public educational institutions in accordance with the vision and mission that has become the objectives and provisions of the educational institution. ${ }^{4}$

The budget is expected to provide detailed planning information of the strategy in action. In addition, the budget will also determine financial statements that affect the financial condition of the organization or educational institution. For example, educational institutions will approve several proposed programs, namely advertising, public relations, student services and parents. Then, the management of the institution will ask for details in detail and separate from each program. The goal is to facilitate the evaluation and assessment of the performance profit of each program. Third, the procedure is also referred to in fairly customary terms as standard operating procedures (SOP). Procedure is a system of steps, techniques that are sequential and describe in detail, detail, about tasks and work completed according to the rules. The procedure is narrowly defined as a variety of activities that must be done to complete the company's programs and tasks. Suppose the community of educational institutions will implement PPDB (Admission of New Learners). The team will develop procedures for ways and techniques to register online as well as offline. The

\footnotetext{
${ }^{4}$ Hunger and Wheelen, 18 .
} 
procedure will also describe in detail the requirements that must be met by the registrant to obtain the PPDB participant's id card. ${ }^{5}$

\section{Research Methods}

This type of research is qualitative by using the approach of social phenomenological interpretation. The level of truth in obtaining data is done holistically and does not rely on a single source of physical observation but rather is based on information that does not appear in detail and detail. ${ }^{6}$ Therefore, this study will try to interpret the social dynamics that occur in SMP Islam al-Azhaar Tulungagung and SMP Negeri 1 Tulungagung by applying the frame of interpretation. The process of extracting data in qualitative research is unique, cannot be generalized through the inductive process to find the meaning behind the existing phenomenon. Thus, researchers are directly involved or passively involved in the field to obtain data correctly and validly in accordance with the focus of research that is the purpose in the study.

\footnotetext{
${ }^{5}$ Hunger and Wheelen,. 18 .

6 Mudji Rahardjo, "Perkembangan Paradigma Metodologi Penelitian: Dari Positivistik, PostPositivistik (Interpretif), Hingga Hermeneutika," Perkembangan Paradigma Metodologi Penelitian: Dari Positivistik, Post-Positivistik (Interpretif),
}

\section{Results and Discussion}

Implementation of strategies in forming effectively is carried out with a process approach. The process can be categorized into two groups, namely, the internal process of the school and the external process of the school. Here are both processes;

\section{Internal School Process}

\section{a. Religious Culture}

Religious strengthening program is a program that is carried out in strengthening and deepening the knowledge of each religion. This program is implemented through techniques literacy. Materials that are used as literacy in the form of religious scriptures respectively. From the literacy activities students are invited to understand textual verses by reading and rewriting them with the understanding and understanding of each student. Not only literacy, but will continue to develop activities on the momentum of the religious holidays that are continuing to occur. For example, character literacy, students are invited to understand about religious figures that can be used as examples, role models, and role model. From these

Hingga Hermeneutika (blog), January 3, 2012, https://konsultanthesis.wordpress.com/2012/01/30/ perkembangan-paradigma-metodologi-penelitiandari-positivistik-post-positivistik-interpretifhingga-hermeneutika/. 
activities' students will know the history of life and the example that can be taken to be a guide for them. Objects that can be used as studies are prophets, scholars, and heroes who contribute to the country.

\section{b. Excellent and Intensive Classes}

Intensive guidance is a special mentoring activity conducted by teachers of certain subjects in order to escort and deliver students to the peak of achievement. This special guidance process is carried out on certain students who will participate in academic activities. With special guidance, students are intensively controlled by the teacher to understand the lesson materials to the maximum. So, intensive guidance program is a program that is implemented to boost academic achievement to the maximum conducted personally or in small groups in a school.

Excellent classes are classes that are formed based on the analysis of academic achievement at the time of school entrance exams. In this excellent class, students are grouped into two, namely upper and lower. Students in the upper category are those who have higher academic achievement compared to other friends. Meanwhile, lower classes are students who have lower academic achievement than other friends. Thus, academic achievement skills can be mapped by the institution concerned, serves to facilitate stressing strengthening or enrichment in the metering of lessons that enter the national exam.

Excellent programs, as mentioned in the previous discussion, the main objectives of strategy formulation include finding distinctive competence of educational institutions - certain skills that become the sources of strength of a school and superior program that can be applied to achieve the goal. From this excellent program, schools will be able to compete and become positive transformative pioneers. The implementation of superior programs will realize effective schools. The implications of the school are said to be effective among others is if the program is able to achieve the targets that have been set.

\section{1) Mini Library}

The availability of facilities and infrastructure becomes an important need in schools. A good program without being supported with adequate facilities and infrastructure will certainly be wishful thinking and difficult to realize. Libraries become one of the important components that cannot be separated in the school component, especially effective schools. Schools are said to be effective, among others supported by adequate facilities and infrastructure, especially libraries. As stated by Mujamil Qomar; the heart of 
education includes teachers/lecturers/ustaz, libraries and laboratories. ${ }^{7}$

The library is the second heart of education after education. The function of the library should be able to pump the spirit in exploring scientific references. Without any passion in visiting, reading, and participating in adding to the library catalogue, literacy cultures will stop and stagnate. Mujamil Qomar emphasizes the need for philosophical transformation towards library management, namely, there is no complete term related to library references. ${ }^{8}$ This means that libraries must be constantly updated on new sciences that continue to evolve. If there is a complete philosophy, it will feel sufficient and there is no need to add more reference treasury. Unstuck that causes interest in visiting the library, becoming lethargic, less passionate especially if supported by library only used as supporting advice, not vital needs. The perception of the library as a means of supporting is the location of the library in the back corner, poorly maintained, walk as it is, there are no officers who intensively manage. If the paradigm is so against the literature then the heart of education will

7 Mujamil Qomar, Strategi Pendidikan Islam (Ciracas, Jakarta: Penerbit Erlangga, 2013). 143144.

${ }^{8}$ Qomar.149. not be able to pump scientific light to the school community, especially students.

From the above analysis can be drawn a proposition that, if the implementation of the strategy of implementing the implementation of facilities and infrastructure in the form of libraries then effective schools will be formed. This is reinforced by the findings of Rika Megasari's research which says the management of facilities and infrastructure is a supporting element to improve the quality of learning. ${ }^{9}$ So, library facilities and infrastructure become one of the supports in creating an effective school.

\section{2) Silent Reading}

Silent reading is a silent or quiet reading activity conducted by students before starting the teaching and learning process. The implementation of this program will be guided or accompanied by the class guardian or the teacher in question in the class. In this program, students are trained and used to love and like reading culture. This reading is an academic culture that must be owned by every student. Without reading and writing activities, it will be difficult to cultivate literacy

\footnotetext{
${ }^{9}$ Rika Megasari, "Peningkatan Pengelolan Sarana Dan Prasarana Pendidikan Untuk Meningkatkan Kualitas Pembelajaran Di SMPN 5 Bukittinggi," Jurnal Administrasi Pendidikan Bahana Manajemen Pendidikan, 1, 2 (2014): 636 - 831.
} 
activities for the school community. So silent reading program will help students in adding insight and knowledge. It will also have an impact on improving the achievement and effectiveness of academic activities in schools.

The above silent reading activities are supported by a mini library in each class to provide books that stimulate students to enjoy reading. One of the efforts made at both institutions is to cultivate silent reading. Reading culture will have a positive impact on the improvement and development of student intelligence, but it is necessary to provide a vehicle and advice that supports the activity. In addition to the parent library that can be accessed by all school communities, it is necessary to provide a mini library. The mini library serves as a stimulus and coercion for students to always meet and face-to-face with books. Without the availability of mini library facilities, it will be difficult to encourage learners to like to read and add insight through the media of books.

The above discussion if communicated with the concept of literacy stages of the implementation of GLS (school literacy movement) which emphasizes on three aspects, namely, a) the

10 Tim Dirjen Kemendikbud, Buku Saku Gerakan Literasi Sekolah, Menumbuhkan Budaya Literasi Di growth of reading interest through the movement of 15 minutes of reading, b) activities in response to reading books, c) improvement of literacy skills in all subjects. ${ }^{10}$ The implementation of strategies in shaping schools is effectively emphasized on the application of literacy culture. The literacy includes programs that can stimulate the interest of students to always be inseparable from reading, writing, and conducting studies, studies and enrichment on all subjects in the school. Deeper enrichment or enrichment of subjects will have an impact on academic and non-academic achievement. The improvement of academic achievement is shown that the achievement of the minimum completion value is exceeded and the national examination (UN) gets the predicate or the best rank passed absolutely. So, it can be said that the implementation of strategies in shaping effective schools through silent reading programs that are in substance an application of the school literacy movement (GLS) can form effective schools.

\section{3) Greenhouse}

Greenhouse synonyms of greenhouse means the engineering of a mini garden to support the effectiveness of teaching and

dan Menengah Kementrian Pendidikan dan Kebudayaan, $\mathrm{tt}) .2$. 
learning activities outside the classroom effectively. Greenhouse includes a facility and infrastructure that supports the education process in order to be achieved to the maximum. A comfortable, safe, shady school environment, and good oxygen intake will have a positive impact on the climate in schools. A positive climate in schools can make a positive contribution to the teaching and learning process. A positive teaching and learning process certainly has an impact on the academic achievement of students.

Mujamil Qomar which states the heart of education includes teachers, libraries, and laboratories. ${ }^{11}$ If medically analysed the heart has four parts namely, the right foyer and the left foyer then the right chamber of the left chamber. So, it takes four components for the heart of education to work to the maximum. The fourth component is a greenhouse or a conducive school environment. The existence of educators, libraries and laboratories but if the environmental conditions are chaotic or not conducive in the teaching and learning process, then there will be problems in the transfer of knowledge. The implementation of strategies in shaping effective schools needs to be supported by the heart of education in the form of; teachers, libraries, laboratories and a conducive environment (greenhouse).

\section{School External Process}

\section{a. Try out}

Try out is a training program of national exam questions that is predicted to come out when the national exam is held. With the try out ability of students will feel and get used to working on national exam questions. Try outs are implemented in the form of independent (internal schools that design predictions of questions) and private try outs or in collaboration with the school's external tutoring services. Each of these institutions will make prediction questions and be tested against students. The result of try out is used as a benchmark to find out how far the learners understand certain subject matter. From the try out will also be known the achievement of the rank/rank of each student. The achievement of the rank or rank is used as evaluation material by the curriculum assessment team, if below average it will be followed up on the tutoring program (tutoring). Meanwhile, if the value of students is above average, then the following task is to do enrichment or improved to achieve the desired goals by the institution. So, try out organized by

\footnotetext{
${ }^{11}$ Qomar, Strategi Pendidikan Islam.149.
} 
educational institutions will be useful to train students in facing national exams, also serves as a benchmark for academic achievement of learners.

\section{b. Strengthening Foreign Languages}

Foreign language education programs that are summarized in intensive activities and habituation in schools become an alternative in developing effective schools. Intensive implementation is carried out in extracurricular activities. Meanwhile, the habituation of this activity is carried out every day in the classroom and outside the classroom. The purpose of this program is, students are invited to love and get used to the international language. Through the international language, students will easily understand the materials in the classroom related to English and Arabic. So, the international language application applied through intensive programs and habituation will help the formation of effective schools.

\section{c. Tahfizul Quran}

Tahfizul Quran is a flagship program that becomes one of the competency distinctions. Distinction competency is a program that distinguishes from one school to another. As discussed earlier, strategic management seeks to conduct assessment actions to determine the strengths and

12 Mortimore, School Effectiveness and the opportunities that can be used to win the competition. Efforts to explore competency until finding an idea and followed up in a program that will give birth to an effective school. Tahfizul Quran program has implications on the lighter emotional intelligence (emotional quotient). Emotional intelligence will have an impact on intelligence. So, the tahfizul quran program will help grow the potential talents and interests of students to achieve the quality of education. If the quality of education of each student is in accordance with expectations, then it can be concluded that the process of teaching and learning activities runs effectively. The statement has relevance to the concept of effective schools delivered by Mortimore that, effective schools are shown as a large number of learners achieving more progress than the expectations set and planned. ${ }^{12}$

Tahfizul Quran as a means to ignite the vibrations of intuition that implicates the awareness of education. Education awareness is a superpower in realizing the success of education. ${ }^{13}$ Educational awareness factors are shown by the behaviour of students who like to read, discipline, skilled and take initiative in doing tasks. So, the tahfizul quran program

\footnotetext{
${ }^{13}$ Qomar, Strategi Pendidikan Islam.6.
} 
is one of the elements to form an effective school.

\section{d. Olympics}

The science Olympics are competition activities outside of school. This activity is carried out to know the excellence of academic achievement between students and even between schools. Through Olympic activities will be known the quality or quality of learners and the quality of the learning process carried out between schools. Students who get the best score or rank in Olympic activities can be categorized as qualified or have good quality. So, it can be said that the teaching and learning process conducted in the school went well and managed to achieve the goals that have been set. The implementation of strategies in forming effective schools is supported by the implementation of Olympic activities.

\section{e. Tazawur and ta'awun}

Tazawur and ta'awun are educational institutions that strive to provide fulfilment of life needs to educators and educational personnel. This program can be realized in the form of the construction of housing facilities and infrastructure and social activities that become the culture of a particular area. Through tazawur and ta'awun programs the performance of
Ustaz/teachers and employees becomes more effective.

The above analysis has relevance to Maslow's hierarchy of needs; physiological needs, security, sense of belonging and compassion, appreciation, and selfactualization. Maslow has the perception that human motivation comes from the five components of such needs. Tazawur and ta'awun programs essentially apply some of the hierarchy of needs that Abraham Maslow inception. So, the implementation of strategies in forming effective schools can be implemented with tazawur and ta'awun programs.

\section{Effective Learning and Effective}

\section{Environment}

The implementation of strategies in forming effective schools is conducted through several stages, namely derived from the philosophy of superior achievement and character and passion of the Rabbani generation. From this philosophy will be breakdown in the realm of teaching and learning effectively. The effective process is sorted into two forms, the internal process of the school and the external process of the school with the results of forming an effective school.

The description above illustrates a pattern of effective learning models, 
effective learning, and a conducive school environment that supports the teaching and learning process. So, the theme that can represent the implementation of strategies in forming effective schools is the existence of effective learning processes, effective learning, and a conducive environment.

\section{Conclusion}

Implementation of strategies in forming effective schools can be taken in several stages, namely; internal processes, including; religious culture, excellent and intensive classes, mini library, silent reading, greenhouse. While external processes, include; try out, strengthening foreign languages, tahfizul quran (memorizing quran), Olympics, tazawur and ta'awun. The implementation of these two aspects, internal processes and external processes will result in a series of activities in the form of, effective learning, effective learning, and an effective learning environment or a conducive climate. This will be the forerunner of the implementation of strategies in shaping effective schools.

\section{Bibliography}

Hunger, J. David, and Thomas L. Wheelen,. Manajemen Strategis. Yogyakarta: Andi, 2003.
Megasari, Rika. "Peningkatan Pengelolan Sarana Dan Prasarana Pendidikan Untuk Meningkatkan Kualitas Pembelajaran Di SMPN 5 Bukittinggi." Jurnal Administrasi Pendidikan Bahana Manajemen Pendidikan, 1, 2 (2014): 636 - 831.

Mortimore, Peter. School Effectiveness and the Management of Effective Learning and Teaching. London: The Internaional Congress For School Effectiveness and Improvement, Noorkoping, Sweden, 1993.

Qomar, Mujamil. Strategi Pendidikan Islam. Ciracas, Jakarta: Penerbit Erlangga, 2013.

Rahardjo, Mudji. "Perkembangan Paradigma Metodologi Penelitian: Dari Positivistik, Post-Positivistik (Interpretif), Hingga Hermeneutika." Perkembangan Paradigma Metodologi Penelitian: Dari Positivistik, Post-Positivistik (Interpretif), Hingga Hermeneutika (blog), January 3, 2012. https://konsultanthesis.wordpress.c om/2012/01/30/perkembanganparadigma-metodologi-penelitiandari-positivistik-post-positivistikinterpretif-hingga-hermeneutika/.

Richards, Jack C., and Richard W. Schmidt. Longman Dictionary of Language Teaching and Applied Linguistics. 4th ed. Harlow: Longman, 2010.

Tim Dirjen Kemendikbud. Buku Saku Gerakan Literasi Sekolah, Menumbuhkan Budaya Literasi Di Sekolah. tp: Direktorat Jendral Pendidikan Dasar dan Menengah Kementrian Pendidikan dan Kebudayaan, tt.

Z., Ulfah Irani, Murniati AR, and Khairuddin. "Implementasi Manajemen Strategik Dalam Upaya 
Implementation of Strategies in Shaping Effective and Superior Schools (Multisite Study at SMP Islam al-Azhaar Tulungagung and SMP Negeri 1 Tulungagung)

Oleh: Tri Prasetiyo Utomo, Imam Saerozi

Peningkatan Mutu Pendidikan Pada

SMAN 10 Fajar Harapan." Jurnal

Administrasi Pendidikan

Pascasarjana Universitas Syiah

Kuala, 2, 4 (2014): 58-70. 